\title{
Pengaruh pembelajaran IPA berbasis discovery learning terintegrasi jajanan lokal daerah terhadap keterampilan proses sains
}

\author{
Rizki Arumning Tyas *, Insih Wilujeng, Suyanta Suyanta \\ Universitas Negeri Yogyakarta. Jalan Colombo No. 1, Karangmalang, Yogyakarta 55281, Indonesia \\ * Corresponding Author. Email: rizkiarumning.2018@student.uny.ac.id
}

Received: 29 November 2019; Revised: 8 July 2020; Accepted: 10 July 2020

\begin{abstract}
Abstrak: Penelitian ini bertujuan untuk mengetahui pengaruh pembelajaran IPA berbasis discovery learning terintegrasi jajanan lokal daerah terhadap keterampilan proses sains. Penelitian ini merupakan penelitian deskriptif dengan pendekatan kuantitatif. Populasi pada penelitian ini adalah peserta didik kelas VIII SMP N1 Cangkringan. Sampel dalam penelitian ini berjumlah 32 peserta didik yang berasal dari satu kelas, yakni kelas VIII A. Perangkat pembelajaran yang digunakan dalam penelitian ini adalah: (1) Silabus, (2) Rencana Pelaksanaan Pembelajaran (RPP), dan (3) Lembar Kegiatan Peserta Didik. Adapun instrumen penelitian yang digunakan dalam penelitian ini adalah lembar observasi keterampilan proses. Aspek yang dianalisis meliputi aspek keterampilan proses sains dasar dan terintergrasi. Setelah diperoleh rata-rata skor pada tiap aspek, ratarata skor yang diperoleh kemudian diklasifikasikan menurut kategori sangat baik, baik, kurang, dan sangat kurang. Berdasarkan hasil penelitian, model pembelajaran IPA berbasis discovery learning terintegrasi jajanan lokal daerah efektif meningkatkan lima aspek keterampilan proses sains dasar, yaitu keterampilan mengobservasi, mengklasifikasi, memprediksi, menarik kesimpulan, dan mengkomunikasikan, serta lima aspek keterampilan proses sains terintegrasi, yaitu menginterpretasi data, mengontrol variabel, membuat hipotesis, mendefinisikan secara operasional, serta melakukan eksperimen.
\end{abstract}

Kata Kunci: pembelajaran IPA, discovery learning, jajanan lokal daerah, keterampilan proses sains

\section{Science learning based on discovery integrated regional local snacks on student science process skills}

\begin{abstract}
This study aimed to determine the effect of science learning based on discovery learning that was integrated with regional local snacks on student science process skills. This research was a descriptive study with a quantitative approach. The population in this research were students of class VIII SMP N1 Cangkringan. The sample in this researchwas 32 students from one class, namely class VIII A. The learning tools used in this study were: (1) Syllabus, (2) Lesson Plan, and (3) Student Worksheet. The research instrument used in this research was the student science process skills observation sheet. The aspects analyzed include aspects of basic and integrated science process skills. After obtaining an average score in each aspect, the average score obtained is then classified according to the category of very good, good, low, and very low. The result shows that discovery learning integrated with regional local snacks is effective in improving five aspects of basic science process skills, namely observing, classifying, predicting, drawing conclusions, and communicating, as well as five aspects of integrated science process skills, namely interpreting data, controlling variables, make hypotheses, define operationally, and conduct experiments.
\end{abstract}

Keywords: science learning, discovery learning, regional local snacks, science process skills

How to Cite: Tyas, R., Wilujeng, I., \& Suyanta, S. (2020). Pengaruh pembelajaran IPA berbasis discovery learning terintegrasi jajanan lokal daerah terhadap keterampilan proses sains. Jurnal Inovasi Pendidikan IPA, 6(1), 114-125. doi:https://doi.org/10.21831/jipi.v6i1.28459

\section{PENDAHULUAN}

Ilmu Pengetahuan Alam (IPA) merupakan sekumpulan pengetahuan tentang gejala alam yang disusun secara sistematis. IPA merupakan suatu produk, proses, dan aplikasi. Produk IPA tidak dapat terwujud tanpa adanya proses. Proses dalam IPA dapat disebut sebagai proses ilmiah yang melalui beberapa tahap eksperimen yaitu observasi (pengamatan), perumusan masalah, perumusan hipotesis, menguji hipotesis, membuat kesimpulan, dan mengkomunikasikan (Trianto, 2014, p. 46). 
Objek IPA meliputi alam semesta dan isinya. IPA merupakan salah satu cabang ilmu pengetahuan yang mempelajari fenomena dan gejala alam yang sering terjadi dalam kehidupan sehari-hari. Salah satu objek yang dapat digunakan sebagai sumber belajar IPA adalah makanan atau jajanan yang biasa ditemui dalam kehidupan sehari-hari. Dalam pelajaran IPA di tingkat pendidikan menengah, materi tersebut dirangkum dalam materi zat aditif makanan. Rostikawati dan Permanasari (2016) telah mengembangkan bahan ajar yang dipadukan dengan materi tersebut, dengan tujuan untuk meningkatkan literasi sains siswa.

Pembelajaran IPA di tingkat pendidikan menengah seharusnya disajikan secara holistik, namun pada kenyataannya pembelajaran IPA belum dapat diterapkan secara terpadu karena masih diajarkan terpisah satu sama lain. Ketersediaan bahan ajar yang bersifat terpadu sangat diperlukan untuk menunjang kegiatan pembelajaran IPA terpadu di SMP. Bahan ajar pada pembelajaran IPA terpadu belum dikembangkan berdasarkan materi-materi yang terkait sesuai dengan kompetensi dasar yang dipadukan. Diperlukan adanya bahan ajar IPA yang terintegrasi sehingga pembelajaran IPA dapat berlangsung secara terpadu. Puspita (2019, p. 80) menyebutkan bahwa dengan adanya bahan ajar terpadu, diharapkan siswa dapat belajar secara mandiri di luar kelas, hal itu juga mendukung pelaksanaan pembelajaran yang lebih efektif di luar jam pelajaran, karena buku paket yang ada sebagai pegangan siswa selama ini masih bersifat umum.

Kenyataan yang terjadi di lapangan sangat jauh dari pengertian IPA terpadu. Guru IPA mengajar semua mata pelajaran fisika, kimia, maupun biologi tanpa menghubungkan ketiganya sebagai bentuk keterpaduan. Selain itu, guru masih menjadi pusat pembelajaran dan menjadi satu-satunya sumber informasi di dalam kelas. Hal tersebut menyebabkan kurangnya keterampilan siswa dalam menghadapi dan memecahkan suatu masalah (Taqiyyah et al., 2017). Guru hanya menyampaikan materi IPA sebagai produk. Kebanyakan guru belum mengajarkan proses menemukan pengetahuannya sendiri melalui kerja ilmiah. Listyawati (2012, p. 62) berpendapat bahwa IPA bukan hanya berkaitan dengan pengetahuan yang berupa konsep, fakta, atau prinsip, melainkan IPA merupakan suatu proses penemuan yang berkaitan secara sistematis.Alasan yang sering dikemukakan guru adalah keterbatasan waktu, lingkungan belajar, dan jumlah peserta didik yang terlalu banyak. Dalam mendukung pembelajaran IPA terpadu, diperlukan Subject Specific Pedagogy (SSP) yaitu perangkat pembelajaran yang dapat memfasilitasi terlaksananya pembelajaran IPA secara terpadu, tidak lagi terpilah-pilah antara fisika, kimia, dan biologi. Dengan demikian, peserta didik dapat memahami IPA secara komprehensif.

SSP IPA disajikan dalam berbagai metode, strategi, maupun model pembelajaran yang dituangkan dalam silabus dan diterjemahkan dalam Rencana Pelaksanaan Pembelajaran (RPP) dengan tujuan untuk mencapai kompetensi yang diharapkan. Salah satu model yang sering digunakan adalah discovery learning. Discovery learning adalah suatu rangkaian kegiatan pembelajaran yang menuntut aktifitas siswa dalam melakukan penyelidikan secara sistematis, kritis, dan logis, sehingga siswa mampu menemukan konsep pembelajaran sendiri (Arends, 2012; Ayadiya \& Sumarni, 2015; Hanafi, 2016; Wenning, 2011).

Berdasarkan penelitian yang dilakukan oleh Fitri \& Derlina (2015, p. 1711) menemukan bahwa model pembelajaran berbasis discovery learning membantu siswa untuk meningkatkan keterampilan dan proses kognitif. Selain itu, pengetahuan yang diperoleh siswa juga bersifat pribadi sehingga sangat membekas dan ampuh. Siswa terdorong untuk melakukan penyelidikan dan hal tersebut akan menimbulkan rasa senang apabila penyelidikan yang dilaksanakan berhasil. Model ini juga memungkinkan siswa belajar sesuai dengan kecepatan dan kemampuannya dengan memanfaatkan berbagai sumber belajar.

Salah satu tujuan pendidikan nasional adalah peserta didik mampu mengembangkan pengalaman melalui percobaan agar dapat merumuskan masalah, mengajukan dan menguji hipotesis, merancang dan merakit instrumen, mengumpulkan, mengolah dan menafsirkan data, serta mengkomunikasikan secara lisan dan tertulis. Sejumlah keterampilan tersebut termasuk kterampilan proses sains. Hal ini menunjukkan bahwa salah satu kemampuan yang harus dilatihkan dalam pembelajaran adalah keterampilan proses sains (Hartini, 2017, p. 19). Keterampilan proses sains bermanfaat bagi siswa dalam mewujudkan partisipasi siswa pada kegiatan pembelajaran. Keterampilan proses sains tidak dapat dipisahkan dalam praktik dari pemahaman konseptual yang terlibat dalam pembelajaran dan penerapan sains (Faqih \& Wilujeng, 2018, p. 192).

Berdasarkan hasil observasi kegiatan pembelajaran yang dilakukan pada peserta didik kelas VIII di SMP N 1 Cangkringan, diketahui bahwa keterampilan proses sains peserta didik masih tergolong rendah. Masih banyak peserta didik yang kurang terampil dalam memprediksi, mengkomunikasikan hasil, 
menginterpretasi data, membuat hipotesis, serta mendefinisikan secara operasional. Selebihnya, pembelajaran belum memfasilitasi tercapainya keterampilan dalam menggunakan angka, mengukur, mengontrol variabel, serta melakukan eksperimen. Berdasarkan uraian di atas, penelitian tentang pengaruh pembelajaran IPA dengan model tertentu yang diintegrasikan dengan objek IPA di sekitar peserta didik dipandang perlu dilakukan, guna mengetahui efektifitas pembelajaran berbasis discovery learning terintegrasi jajanan lokal daerah terhadap keterampilan proses sains.

\section{METODE}

Penelitian ini merupakan penelitian deskriptif kuantitatif, dimana penelitian menjabarkan secara desktiptif sesuai hasil pengamatan serta melakukan pengukuran secara kuantitatif menggunakan statistik sederhana dengan menghitung rata-rata keterampilan proses sains peserta didik. Penelitian dilakukan di SMP N 1 Cangkringan yang dilaksanakan pada semester ganjil tahun ajaran 2019/2020, tepatnya pada bulan Oktober 2019. Populasi dalam penelitian ini adalah peserta didik kelas VIII SMP N 1 Cangkringan tahun ajaran 2019/2020 sebanyak 4 kelas, yaitu kelas VIII A, VIII B, VIII C, dan VIII D. Jumlah total populasi adalah 122peserta didik. Sampel dalam penelitian ini berjumlah 32 peserta didik yang berasal dari satu kelas, yakni kelas VIII A. Pengambilan sampel dilakukan berdasarkan teknik purposive sampling, yaitu teknik penentuan sampel dengan pertimbangan tertentu (Sugiyono, 2015b, p. 118). Penentuan kelas VIII A sebagai sampel penelitian berdasarkan dari pertimbangan akademik guru.

Teknik pengumpulan data untuk memperoleh data yang berkaitan dengan keterampilan proses sains adalah dengan menggunakan lembar observasi keterampilan proses sains yang diisi oleh observer. Lembar observasi keterampilan proses sains diisi setiap pelaksanaan pembelajaran, hal ini bertujuan untuk mengetahui peningkatan keterampilan proses sains. Instrumen pengumpulan data yang digunakan adalah lembar observasi keterampilan proses sains yang dibagi menjadi keterampilan proses sains dasar dan keterampilan proses sains terintegrasi. Adapun kisi-kisi dan indikator lembar observasi keterampilan proses sains dapat dilihat pada Tabel 1.

Tabel 1. Aspek dan Indikator Keterampilan Proses Sains Dasar

\begin{tabular}{|c|c|c|}
\hline No. & $\begin{array}{l}\text { Aspek Keterampilan } \\
\text { Proses }\end{array}$ & Indikator \\
\hline 1. & Mengobservasi & $\begin{array}{l}\text { Menggunakan beberapa atau semua alat indera untuk mengumpulkan informasi } \\
\text { dari objek } \\
\text { Merasakan perbedaan dan persamaan antara objek } \\
\text { Mencocokan objek pengamatan dengan deskripsi yang telah diberikan } \\
\text { Mengidentifikasi karakteristik objek (bentuk, warna, ukuran, dan tekstur) }\end{array}$ \\
\hline 2. & Mengklasifikasi & $\begin{array}{l}\text { Mengidentifikasi karakteristik yang berguna untuk mengklasifikasikan objek } \\
\text { Mengelompokkan dan memperhatikan kekonsistenan data } \\
\text { Mengelompokkan objek berdasarkan karakteristik masing-masing/persamaan } \\
\text { dan perbedaan/kriteria/karakter yang dapat diamati } \\
\text { Membangun dan menggunakan sistem klasifikasi dalam tabulasi atau bentuk } \\
\text { visualisasi }\end{array}$ \\
\hline 3. & Memprediksi & $\begin{array}{l}\text { Mengemukakan apa yang akan mungkin terjadi } \\
\text { Menggunakan fakta-fakta untuk merumuskan urutan proses berikutnya } \\
\text { Menggunakan pola/hubungan untuk memperhitungkan kasus dimana tidak ada } \\
\text { informasi terkumpul } \\
\text { Meramal peristiswa/kejadian berdasarkan observasi/pengalaman sebelumnya/ } \\
\text { pola tertentu dari data yang terpercaya }\end{array}$ \\
\hline 4. & Menarik kesimpulan & $\begin{array}{l}\text { Membuat kesimpulan berdasarkan data pengamatan } \\
\text { Menyimpulkan fakta, konsep, dan prinsip yang diketahui } \\
\text { Menarik kesimpulan data empiris hasil percobaan/pengamatan dengan } \\
\text { grafik/tabel/diagram } \\
\text { Mengkaitkan hasil percobaan atau kegiatan dengan teori yang ada }\end{array}$ \\
\hline 5. & Mengkomunikasikan & $\begin{array}{l}\text { Menyampaikan hasil pengamatan secara sistematis } \\
\text { Mengubah informasi dalam bentuk lain, seperti grafik, tabel, dan diagram } \\
\text { Membaca informasi yang diberikan dalam bentuk grafik, tabel, dll } \\
\text { Memutuskan langkah terbaik dari informasi yang menampilkan jenis tertentu }\end{array}$ \\
\hline
\end{tabular}


Jurnal Inovasi Pendidikan IPA, 6 (1), 2020 - 117

Rizki Arumning Tyas, Insih Wilujeng, Suyanta Suyanta

Tabel 2. Aspek dan Indikator Keterampilan Proses Sains Terintegrasi

\begin{tabular}{|c|c|c|}
\hline No. & $\begin{array}{c}\text { Aspek Keterampilan } \\
\text { Proses }\end{array}$ & Indikator \\
\hline 1. & $\begin{array}{l}\text { Menginterpretasi } \\
\text { data }\end{array}$ & $\begin{array}{l}\text { Mengidentifikasi hubungan antar variabel, dari grafik/tabel yang diberikan dari } \\
\text { data (menghubungkan dengan investigasi) } \\
\text { Menarik kesimpulan dari data dengan menentukan pola yang jelas } \\
\text { Menyusun kesimpulan yang beralasan yang menghubungkan kecenderungan } \\
\text { dalam data terhadap variabel } \\
\text { Melakukan penilaian terhadap keabsahan, ketepatan, dan kegunaan data }\end{array}$ \\
\hline 2. & Mengontrol variabel & $\begin{array}{l}\text { Mengidentifikasi variabel bebas, variabel terikat, dan variabel kontrol } \\
\text { Mengidentifikasi variabel-variabel yang dapat mempengaruhi hasil eksperimen, } \\
\text { menjaga sebagian besar tetap selama memanipulasi kecuali variabel bebas } \\
\text { Mengidentifikasi variabel-variabel yang mungkin mempengaruhi variabel } \\
\text { terikat sebagaimana dinyatakan dalam problem } \\
\text { Mengontrol dan memperlakukan variabel secara benar dan tepat }\end{array}$ \\
\hline 3. & Membuat hipotesis & $\begin{array}{l}\text { Mengidentifikasi pertanyaan/pernyataan yang dapat/ tidak dapat di uji } \\
\text { Menyusun pernyataan, misalnya pertanyaan, inferensi, prediksi, yang dapat di } \\
\text { uji dengan eksperimen } \\
\text { Membuat dugaan yang dianggap benar mengenai adanya suatu faktor yang } \\
\text { terdapat dalam satu situasi } \\
\text { Menduga ada akibat tertentu yang akan timbul karena ada factor tersebut secara } \\
\text { tepat }\end{array}$ \\
\hline 4. & $\begin{array}{l}\text { Mendefinisikan } \\
\text { secara operasional }\end{array}$ & $\begin{array}{l}\text { Menyatakan bagaimana untuk mengukur sebuah variabel eksperimen serta } \\
\text { menggambarkan keterbatasannya } \\
\text { Mendefinisikan variabel berdasarkan perilaku/cara kerja untuk dilakukan } \\
\text { Memformulasikan pernyataan bermakna yang menghasilkan pemahaman } \\
\text { Merumuskan parameter eksperimental definisi operasional seperti batas, } \\
\text { prosedur, pengumpulan data, dan interaksi antar variabel }\end{array}$ \\
\hline 5. & $\begin{array}{l}\text { Melakukan } \\
\text { eksperimen }\end{array}$ & $\begin{array}{l}\text { Mengidentifikasi apa yang diukur/dibandingkan dalam investigasi yang } \\
\text { diberikan } \\
\text { Memilih desain investigasi yang sesuai untuk menguji hipotesis } \\
\text { Mengenali batasan metode dan alat yang digunakan dalam eksperimen, } \\
\text { misalnya error eksperimen } \\
\text { Menggunakan prosedur yang aman serta peralatan yang sesuai selama } \\
\text { melakukan percobaan }\end{array}$ \\
\hline
\end{tabular}

Analisis data dilakukan untuk mengetahui rata-rata penguasaan keterampilan proses sains di setiap indikatornya, baik pada keterampilan proses sains dasar maupun terintegrasi. Lembar observasi keterampilan proses sains dinilai oleh observer pada saat kegiatan belajar mengajar berlangsung dengan mengacu penilaian pada rubrik yang sudah disediakan oleh peneliti. Pengisian data hasil observasi dilakukan dengan memberikan tanda checklist $(\sqrt{ })$ pada skor yang sesuai dengan hasil pengamatan yang dilakukan oleh observer.

Hasil pada masing-masing aspek dapat dianalisis dengan menggunakan Persamaan Rumus 1. Diketahui bahwa $\overline{\boldsymbol{x}}$ adalah rata-rata skor pada tiap aspek; $\boldsymbol{\Sigma} \boldsymbol{n}$ adalah jumlah skor yang diperoleh; dan $\boldsymbol{\Sigma} \boldsymbol{f}$ adalah jumlah responden peserta didik.

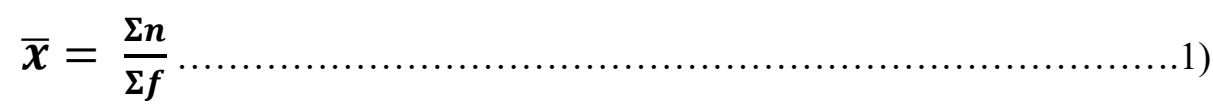

Aspek yang dianalisis meliputi aspek keterampilan proses sains dasar dan terintergrasi. Setelah diperoleh rata-rata skor pada tiap aspek, rata-rata skor yang diperoleh kemudian diklasifikasikan mengacu pada panduan menurut Widoyoko (2017, p. 74) dengan tingkatan kategori seperti pada Tabel 3.

Tabel 3. Kategori Tingkat Penguasaan Keterampilan Proses Sains

\begin{tabular}{ccc}
\hline No. & Interval rata-rata skor & Kategori \\
\hline 1. & $3,25<\mathrm{X} \leq 4,00$ & Sangat Baik \\
2. & $2,50<\mathrm{X} \leq 3,25$ & Baik \\
3. & $1,75<\mathrm{X} \leq 2,50$ & Kurang \\
4. & $1,00<\mathrm{X} \leq 1,75$ & Sangat Kurang \\
\hline
\end{tabular}


Jurnal Inovasi Pendidikan IPA, 6 (1), 2020 - 118

Rizki Arumning Tyas, Insih Wilujeng, Suyanta Suyanta

\section{HASIL DAN PEMBAHASAN}

Pembelajaran IPA berbasis discovery learning terintegrasi jajanan lokal daerah dilaksanakan untuk memfasilitasi materi zat aditif dan adiktif pada kelas VIII Semester 1, tepatnya pada KD 3.6 yang berbunyi 3.6 memahami berbagai zat aditif dalam makanan dan minuman, zat adiktif, serta dampaknya terhadap kesehatan. Kegiatan pembelajaran dibagi menjadi 2 pertemuan, pada pertemuan pertama peserta didik melakukan kegiatan praktikum pengujian kandungan zat pewarna pada berbagai jajanan lokal daerah dan pada pertemuan kedua peserta didik melakukan kegiatan praktikum pengujian kandungan zat pengawet pada berbagai jajanan lokal daerah. Dalam melakukan kegiatan, peserta didik dibekali dengan Lembar Kegiatan Peserta Didik (LKPD) dan handout yang berisi materi pembelajaran.

Secara umum, langkah implementasi Discovery Learning menurut Djamarah \& Zain (2013, p. 42); Hanafi (2016, p. 292); dan Syah (2013, p. 68) dibagi menjadi beberapa sintaks atau langkah pembelajaran, yang terdiri dari stimulation stage, problem statement stage, data collection stage, data procession stage, verification stage, dan generalization. Pemilihan model pembelajaran berbasis discovery learning adalah karena model pembelajaran berbasis discovery learning memiliki beberapa kelebihan, antara lain menjadikan peserta didik aktif dalam berpikir kritis dan meningkatkan aktivitas pembelajaran peserta didik, memaksimalkan keterlibatan peserta didik dalam pembelajaran, membangun sikap kerja sama dan dinamika tim dalam pemecahan masalah, melatih keterampilan dan ketangkasan peserta didik dalam menyelesaikan soal, serta melatih peserta didik untuk mengaplikasikan pengetahuan yang diperoleh Sulistyowati et al. (2012).

Berdasarkan penelitian yang telah dilakukan terhadap lima aspek keterampilan proses sains dasar yang meliputi keterampilan mengobservasi, mengklasifikasi, memprediksi, menarik kesimpulan, dan mengkomunikasikan terhadap 32 peserta didik kelas VIII A SMP N 1 Cangkringan, diperoleh data hasil yang dipaparkan pada Tabel 4.

Tabel 4. Data Hasil Pengamatan Keterampilan Proses Sains Dasar

\begin{tabular}{|c|c|c|c|c|c|}
\hline \multirow{3}{*}{ No. } & \multirow{3}{*}{ Aspek Keterampilan Proses } & \multicolumn{4}{|c|}{ Hasil Observasi } \\
\hline & & \multicolumn{2}{|c|}{ Pertemuan ke-1 } & \multicolumn{2}{|c|}{ Pertemuan ke- 2} \\
\hline & & Rerata & Kategori & Rerata & Kategori \\
\hline 1. & Mengobservasi & 3 & Baik & 4 & Sangat Baik \\
\hline 2. & Mengklasifikasi & 2,5625 & Baik & 3,8125 & Sangat Baik \\
\hline 3. & Memprediksi & 1,75 & Sangat Kurang & 3,75 & Sangat Baik \\
\hline 4. & Menarik Kesimpulan & 2,3125 & Kurang & 3,5625 & Sangat Baik \\
\hline 5. & Mengkomunikasikan & 2,8125 & Baik & 3,5 & Sangat Baik \\
\hline
\end{tabular}

Berdasarkan data hasil pengamatan keterampilan proses sains dasar tersebut, secara umum, diketahui bahwa terdapat peningkatan yang signifikan terhadap kelima aspek keterampilan proses sains dasar yang diukur pada pembelajaran pertemuan pertama dan pertemuan kedua. Berdasarkan hasil wawancara kepada guru, diketahui bahwa guru jarang atau bahkan hampir tidak pernah menggunakan model pembelajaran berbasis discovery learning. Hal ini menyebabkan peserta didik belum terbiasa melakukan pembelajaran yang menuntut aktifitas peserta didik. Peserta didik terbiasa diberi materi secara langsung oleh guru dengan menggunakan metode ceramah, sehingga menyebabkan peserta didik kurang terampil dalam beberapa aspek. Namun, pada pertemuan kedua, peserta didik semua aspek keterampilan proses sains yang diukur mengalami peningkatan, seperti pada Gambar 1.

Keterampilan proses sains tidak hanya mampu mendorong siswa untuk menemukan konsep, tetapi juga mampu mendorong siswa untuk berpikir kritis. Melalui keterampilan proses sains, siswa akan menggunakan pikirannya untuk menerapkan berbagai konsep atau prinsip. Padilla (1990); dan Ratnasari et al. (2017) juga menyebutkan bahwa keterampilan proses sains mampu membekali siswa melakukan berbagai kegiatan fisik selama proses penemuan maupun keterampilan berfikir dan menanamkan sikap ilmiah. Dalam proses penemuan (discovery), siswa melakukan berbagai aktivitas seperti mengamati, mengukur, memprediksi, menganalisis, dan menyimpulkan sehingga siswa mampu membentuk konsep dasar (prior knowledge) didalam pikirannya (Ratnasari et al., 2017).

Dalam model discovery learning keterampilan mengobservasi, mengklasifikasi, dan memprediksi difasilitasi pada sintaks stimulation stage dan problem statement stage. Pada tahap stimulation stage, guru memulai kegiatan belajar mengajar dengan mengajukan pertanyaan, menyarankan untuk membaca buku, dan kegiatan belajar lain yang mengarah pada masalah. Stimulasi pada tahap ini berfungsi untuk membangun kondisi interaktif dalam pembelajaran yang dapat membantu siswa untuk lebih aktif dalam 
mengeksplorasi materi (Djamarah \& Zain, 2010). Sedangkan pada tahap problem statement stage guru memberikan kesempatan kepada siswa untuk mengidentifikasi masalah sebanyak mungkin yang berkaitan dengan materi pembelajaran. Permasalahan yang dipilih kemudian dirumuskan dalam bentuk pertanyaan dan hipotesis (Hanafi, 2016).

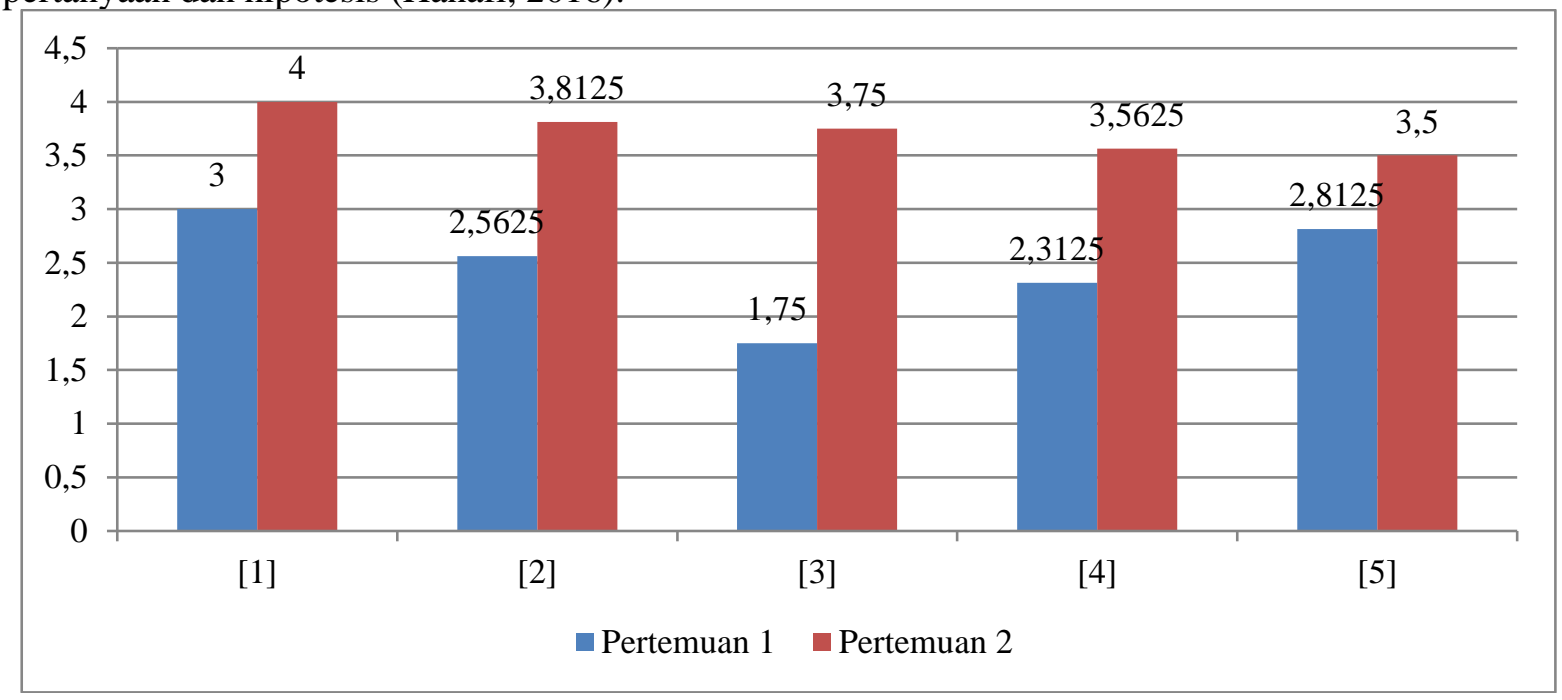

Gambar 1. Peningkatan Aspek Keterampilan Proses Sains Dasar pada Pertemuan ke-1 dan ke-2

Pada tahap stimulation stage dan problem statement stage, peserta didik dihadapkan pada masalah yang sudah direkayasa oleh guru sehingga peserta didik tidak perlu mengerahkan seluruh pikiran dan keterampilannya untuk mendapatkan temuan dalam masalah yang disajikan (Widiadnyana et al., 2014, p. 3). Selain itu, karena masalah yang disajikan oleh guru merupakan hal yang sangat dekat dengan kehidupan sehari-hari, yakni berkaitan dengan makanan lokal daerah, peserta didik lebih mudah dalam melakukan observasi dan klasifikasi.

Mengitegrasikan kearifan lokal dalam pembelajaran dapat memberikan suasana belajar yang bermakna. Kebermaknaan yang dimaksud adalah siswa mempelajari hal-hal yang sesuai dengan konteks siswa tersebut berada. Selain itu, berdasarkan penelitian yang dilakukan oleh Wilujeng et al. (2017) terhadap peserta didik kelas VII dan VIII SMP, diperoleh hasil bahwa pembelajaran yang diintegrasikan dengan potensi lokal sangat efektif dilaksanakan, dilihat dari beberapa aspek keterampilan IPA, seperti keterampilan proses, keterampilan umum, kemampuan berpikir kritis, dan sikap ilmiah IPA. Sya`ban dan Wilujeng (2016) mendukung hal tersebut dengan penelitian yang dilakukan dengan mengembangkan SSP zat dan energi berbasis keunggulan lokal, pengembangan tersebut layak digunakan dengan penilaian yang sangat baik serta efektif untuk meningkatkan literasi sains siswa.

Berbanding terbalik dengan penelitian yang dilakukan oleh Elvanisi et al. (2018) diketahui bahwa aspek memprediksi merupakan aspek dengan skor tertinggi. Tingginya skor keterampilan proses sains pada aspek memprediksi karena peserta didik dilatih menemukan suatu pengetahuan secara mandiri (Ayadiya \& Sumarni, 2015). Keterampilan proses sains pada aspek memprediksi dapat dilatih dengan metode pembelajaran diskusi dan praktikum. Berdasarkan hasil penelitian yang dilakukan oleh Siska et al. (2013) tingginya aspek memprediksi dikarenakan peserta didik dilatih menemukan konsep-konsep dan prinsip-prinsip melalui kegiatan percobaan atau praktikum. Wajar kiranya apabila skor memprediksi pada peserta didik kelas VIII A SMP N 1 Cangkringan memperoleh hasil 1,75 dengan kategori sangat kurang pada pertemuan ke-1. Hal ini dikarenakan peserta didik jarang atau bahkan tidak pernah diajak untuk melakukan kegiatan praktikum. Dari hasil wawancara, diketahui bahwa terakhir peserta didik diajak melakukan kegiatan praktikum adalah pada saat peserta didik masih duduk di kelas VII. Pada pertemuan kedua, skor memprediksi pada peserta didik kelas VIII A SMP N 1 Cangkringan mengalami peningkatan yang signifikan, yaitu memperoleh hasil 3,75 dengan kategori sangat baik. Dengan demikian, diketahui bahwa pembelajaran dengan model discovery learning terintegrasi jajanan lokal daerah efektif meningkatkan keterampilan proses sains. Pembelajaran yang menekankan pada pengalaman nyata melalui hal-hal yang lekat dengan kehidupan sehari-hari menyebabkan peserta didik memiliki antusiasme dalam mengikuti kegiatan belajar mengajar dan meningkatkan aspek-aspek keterampilan proses sains (Rahardini et al., 2017). 
Dalam model discovery learning keterampilan menarik kesimpulan difasilitasi pada sintaks verification. Pada tahap verification, peserta didik melakukan pemeriksaan yang cermat untuk membuktikan apakah hipotesisnya telah terbukti atau tidak, terkait dengan hasil pemrosesan data yang telah dilakukan. Guru memberikan arahan dan verifikasi berkaitan dengan hasil pekerjaan siswa yang telah dilakukan sebelumnya. Verifikasi yang diberikan oleh guru diawali dengan siswa yang saling melakukan verifikasi pekerjaan antar kelompok melalui kegiatan diskusi dan presentasi. Sehingga, kegiatan belajar mengajar tetap berorientasi pada aktifitas dan kegiatan siswa.

Berdasarkan hasil penelitian, diketahui bahwa pada pertemuan pertama, skor menarik kesimpulan peserta didik aalah 2,3125 dengan kategori kurang, sedangkan pada pertemuan kedua mengalami peningkatan dengan memperoleh skor 3,5625 dengan kategori sangat baik. Sintaks verification mendukung tercapainya keterampilan menarik kesimpulan, karena pada tahap verification peserta didik dipandu dalam merumuskan proses kognitif yang diuraikan menjadi langkah-langkah konkret, kemudian digunakan sebagai panduan berpikir (Mundilarto, 2015, p. 76).

Proses pembelajaran IPA di SMP N 1 Cangkringan belum melatihan keterampilan proses sains kepada peserta didik, serta belum dilakukan penilaian khusus untuk menilai aspek-aspek keterampilan proses sains. Kemampuan kognitif masih menjadi prioritas guru, keterampilan proses sains hanya dilatihkan saat praktikum, sementara pembelajaran dengan praktikum juga jarang dilakukan. Hal ini menyebabkan peserta didik memerlukan adaptasi dalam pelatihan keterampilan proses sains, sehingga pada pertemuan pertama skor yang diperoleh tidak terlalu tinggi, namun, mengalami peningkatan pada pertemuan kedua. Padahal, implementasi kurikulum 2013 mensyaratkan guru mampu memberikan penilaian terhadap pengetahuan, sikap, dan keterampilan sekaligus. Dengan demikian, proses penilaian pada kurikulum 2013 tidak hanya terfokus pada aspek kognitif saja (Ratnasari et al., 2017).

Berdasarkan hasil penelitian, diketahui bahwa pada pertemuan pertama, skor mengkomunikasikan adalah 2,8125 dengan kategori baik, sedangkan pada pertemuan kedua mengalami peningkatan dengan memperoleh skor 3,5 dengan kategori sangat baik. Hal tersebut sejalan dengan penelitian yang dilakukan oleh Mundilarto (2015, p. 77) bahwa pembelajaran IPA terintegrasi efektif dapat meningkatkan berbagai aspek keterampilan proses sains. Selain itu, Hayati et al. (2019, p. 248) yang mengembangkan modul potensi lokal berbasis SETS juga efektif meningkatkan keterampilan proses sains dan membantu siswa memahami pelajaran. Mendukung hal tersebut, Irianti dan Nurcahyo (2016, p. 122) menyebutkan bahwa salah satu faktor yang mendorong peningkatan keterampilan proses sains adalah dengan diberlakukannya pembelajaran yang memacu aktifitas siswa.

Keterampilan komunikasi yang baik adalah ketika peserta didik mampu menyampaikan sesuatu secara runtut, baik secara lisan maupun tulisan (Elvanisi et al., 2018). Keterampilan komunikasi secara lisan meliputi kemampuan berbicara peserta didik, yang harus mampu menunjukkan kemahiran dalam memilih dan menggunakan kalimat, sehingga, informasi yang hendak disampaikan dapat diterima secara mudah oleh pendengarnya. Adapun keterampilan komunikasi secara tulisan merupakan kemampuan dalam mentransfer dan menyajikan pengetahuan secara konsisten, baik dalam bentuk tulisan, gambar, maupun data dalam bentuk tabel atau grafik.

Selain lima aspek keterampilan proses sains dasar, terdapat lima aspek keterampilan proses sains terintegrasi yang diukur terhadap 32 siswa kelas VIII SMP N 1 Cangkringan, meliputi menginterpretasi data, mengontrol variabel, membuat hipotesis, mendefinisikan secara operasional, serta melakukan eksperimen. Hasil yang diperoleh dipaparkan pada Tabel 5.

Tabel 5. Data Hasil Pengamatan Keterampilan Proses Sains Terintegrasi

\begin{tabular}{llcccc}
\hline \multirow{2}{*}{ No. } & \multirow{2}{*}{ Aspek Keterampilan Proses } & \multicolumn{4}{c}{ Hasil Observasi } \\
\cline { 3 - 5 } & & \multicolumn{2}{c}{ Pertemuan ke-1 } & Pertemuan ke-2 \\
\cline { 3 - 5 } & & Rerata & Kategori & Rerata & Kategori \\
\hline 1. & Menginterpretasi Data & 2,75 & 3,375 & Sangat Baik \\
2. & Mengontrol Variabel & 3,3125 & Sangat Baik & 3,4375 & Sangat Baik \\
3. & Membuat Hipotesis & 1,8125 & Kurang & 3,75 & Sangat Baik \\
4. & Mendefinisikan Secara Operasional & 3,1875 & Baik & 3,25 & Baik \\
5. & Melakukan Eksperimen & 4 & Sangat Baik & 4 & Sangat Baik \\
\hline
\end{tabular}

Berdasarkan hasil pada Tabel 5, secara umum, diketahui bahwa terdapat peningkatan yang signifikan terhadap keempat aspek keterampilan proses sains terintegrasi yang diukur pada pembelajaran pertemuan pertama dan pertemuan kedua. Untuk keterampilan melakukan eksperimen, baik pada pertemuan 
pertama maupun pertemuan kedua, skor yang diperoleh peserta didik adalah 4, dengan kategori sangat baik. Hal tersebut mungkin dikarenakan siswa merasa senang dengan kegiatan eksperimen yang dilakukan, sehingga berusaha semaksimal mungkin mengikuti kegiatan belajar mengajar. Subekti \& Ariswan (2016, p. 252) menyebutkan bahwa metode eksperimen meningkatkan keterampilan proses sains siswa secara signifikan.

Pembelajaran dengan metode eksperimen menuntut peserta didik untuk terlibat aktif dalam melakukan kegiatan, membuktikan hipotesis, serta menarik kesimpulan tentang objek yang dipelajarinya, sehingga peserta didik terlatih untuk merekam semua fakta dan data yang diperoleh dari kegiatan yang dilakukan, bukan hanya sekedar opini rekayasa pemikiran (Djamarah \& Zain, 2010). Pernyataan tersebut didukung oleh penelitian yang dilakukan oleh Subekti \& Ariswan, (2016, p. 260) yang menyatakan bahwa pembelajaran dengan metode eksperimen sebaiknya diterapkan di sekolah, hal tersebut erat kaitannya dengan peningkatan hasil belajar serta keterampilan proses sains peserta didik dalam mempelajari materi, khususnya materi yang dapat dipelajari dengan cara praktikum atau eksperimen.

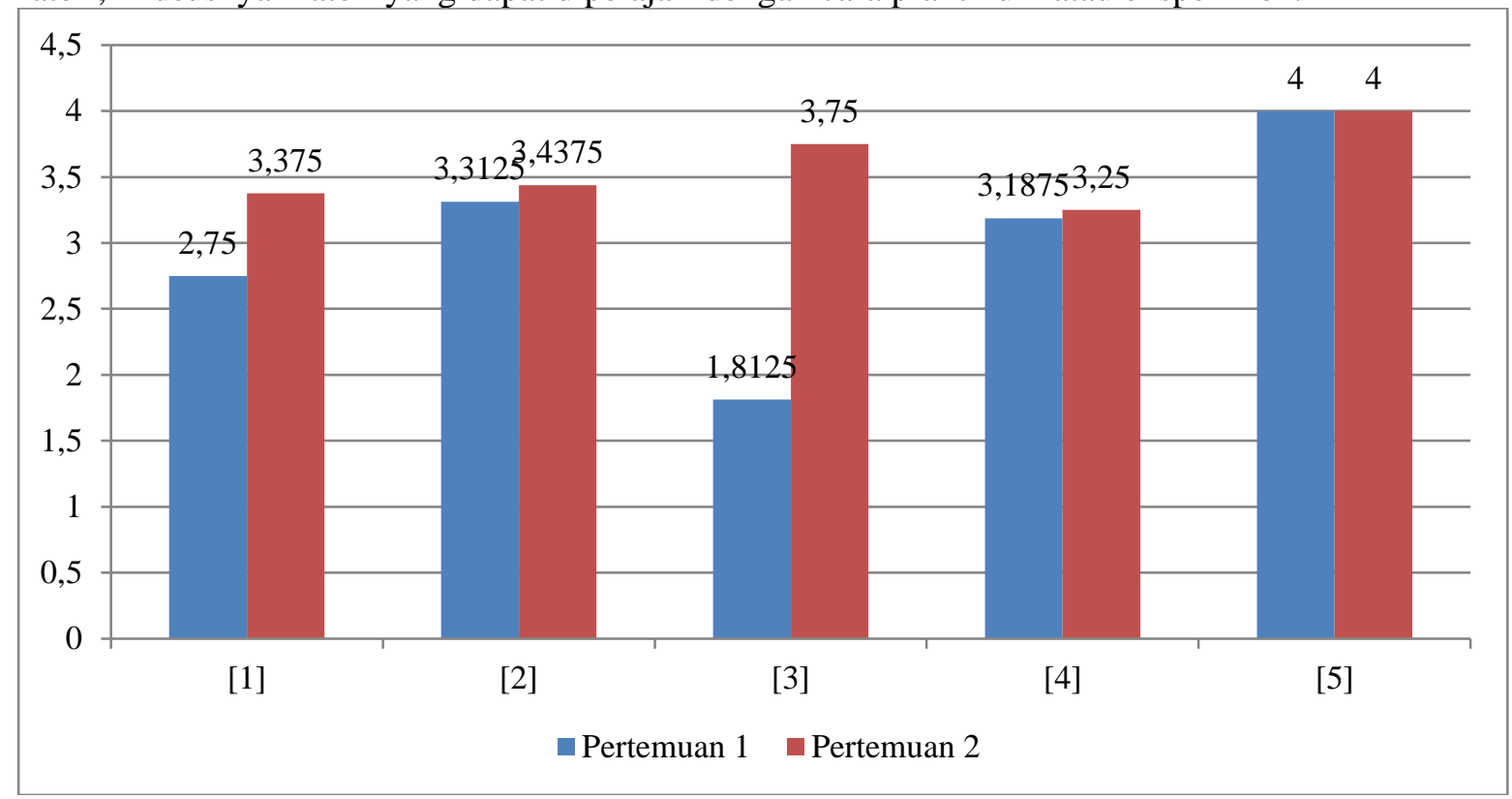

Gambar 2. Peningkatan Aspek Keterampilan Proses Sains Terintegrasi pada Pertemuan ke - 1 dan ke - 2

Dalam model discovery learning, keterampilan menginterpretasi data, mengontrol variabel, membuat hipotesis, mendefinisikan secara operasional, serta melakukan eksperimen difasilitasi dalam sintaks data collection, data procession, dan generalization. Pada tahap data collection, peserta didik diberi kesempatan untuk melakukan percobaan atau eksplorasi untuk menjawab pertanyaan dan membuktikan hipotesis yang telah dirumuskan sebelumnya. Guru memberikan kesempatan bagi peserta didik untuk mengumpulkan sebanyak mungkin informasi yang relevan. Data dapat diperoleh melalui membaca literatur, mengamati objek, mewawancarai sumber, melakukan eksperimen sendiri, dan sebagainya. Sedangkan, pada tahap data procession, peserta didik mengolah data dan informasi yang telah diperoleh siswa melalui wawancara, observasi, dan sebagainya. Data dan hasil observasi kemudian diinterpretasikan. Pada tahap generalization, peserta didik menarik kesimpulan yang dapat digunakan sebagai pengetahuan dengan memperhitungkan hasil verifikasi. Berdasarkan hasil verifikasi maka prinsip dasar generalisasi dirumuskan.

Berdasarkan hasil penelitian, aspek yang mempunyai skor terendah adalah aspek merumuskan hipotesis dengan skor 1,812 dan kategoru kurang. Pada kegiatan pembelajaran yang dilakukan, peserta didik disajikan beberapa gambar yang diharapkan dapat memacu peserta didik dalam merumuskan hipotesis. Namun, keterampilan merumuskan hipotesis belum muncul. Hal tersebut mungkin dikarenakan gambar yang disajikan kurang dapat merangsang peserta didik untuk merumuskan hipotesis. Faktor lain yang mungkin terjadi adalah ketidaktahuan peserta didik dengan istilah hipotesis. Hal ini diperkuat dengan wawancara yang dilakukan kepada beberapa peserta didik yang diawali dengan pertanyaan mengenai definisi hipotesis.

Pada penelitian yang dilakukan oleh Ratnasari et al. (2017, p. 174) diketahui bahwa dari sekian aspek keterampilan proses sains, aspek yang indikator kemunculannya rendah adalah keterampilan 
dalam merumuskan hipotesis. Rendahnya skor merumuskan hipotesis dapat disebabkan oleh sempitnya pnegetahuan peserta didik, sehingga merujuk pada sedikitnya peserta didik yang mampu membuat dugaan sementara atas apa yang diinstruksikan oleh guru (Kartimi et al., 2013).

Keterampilan proses sains aspek merumuskan hipotesis dapat dilatih dengan mengajak peserta didik merumuskan hipotesis sebelum melaksanakan kegiatan praktikum. Tetapi berdasarkan hasil wawancara dan observasi, peserta tidak pernah melakukan kegiatan praktikum, hal inilah menjadi salah satu faktor penyebab rendahnya keterampilan peserta didik dalam merumuskan hipotesis. Pada pertemuan ke dua, aspek merumuskan hipotesis mengalami peningkatan yang signifikan, hal ini membuktikan pernyataan tersebut, bahwa peserta didik hanya membutuhkan pembiasaan-pembiasaan untuk dapat terampil dalam menguasai semua aspek.

Secara umum, pembelajaran dengan model discovery learning dapat meningkatkan lima aspek keterampilan proses sains dasar dan terintegrasi.Pembelajaran dengan model discovery menuntut siswa untuk dapat menemukan konsep-konsep dan prinsip-prinsip melalui proses mentalnya sendiri (Rosnaeni et al., 2018, p. 51). Hal ini dapat menguntungkan, karena pembelajaran berpusat pada siswa, siswa diberi pengalaman secara langsung sehingga siswa lebih aktif dan lebih termotivasi dalam mengikuti pembelajaran. Sesuai dengan pendapat Rusman (2016, p. 42) dan Sugiyono (2015, p. 22) bahwa dengan pembelajaran yang mengaktifkan siswa, siswa akan mempunyai otonomi dalam belajar. Siswa diperbolehkan untuk andil dalam menentukan tujuan pembelajaran, sesuai dengan kebutuhan belajar dan kecepatan belajarnya sendiri. Kegiatan belajar yang dapat mendorong pembelajaran berorientasi pada siswa antara lain melalui strategi pembentukan tim, strategi penilaian sederhana melalui kuis, strategi perlibatan belajar langsung, stimulasi diskusi kelas, pembelajaran sebaya, penerapan pembelajaran kooperatif, penerapan pembelajaran berbasis masalah, dan lain sebagainya.

Selain itu, pembelajaran dengan model discovery learning menunjukkan bahwa pengetahuan yang diperoleh siswa juga bersifat pribadi sehingga sangat membekas dan ampuh. Siswa terdorong untuk melakukan penyelidikan dan hal tersebut akan menimbulkan rasa senang apabila penyelidikan yang dilaksanakan berhasil. Model ini juga memungkinkan siswa belajar sesuai dengan kecepatan dan kemampuannya dengan memanfaatkan berbagai sumber belajar.

Sulistyowati et al. (2012, p. 6) dalam penelitiannya menemukan bahwa model pembelajaran berbasis discovery learning memiliki beberapa kelebihan, antara lain menjadikan siswa aktif dalam berpikir kritis dan meningkatkan aktivitas pembelajaran siswa, memaksimalkan keterlibatan siswa dalam pembelajaran, membangun sikap kerjasama dan dinamika tim dalam pemecahan masalah, melatih keterampilan dan ketangkasan siswa dalam menyelesaikan soal, serta melatih siswa untuk mengaplikasikan pengetahuan yang diperoleh. Roestiyah $(2012$, p. 68) menemukan bahwa model pembelajaran berbasis discovery learning memberikan kesempatan pada siswa untuk maju dan berkembang sesuai kemampuan masing-masing, membantu mengarahkan cara belajar peserta didik, serta memperkuat dan menambah kepercayaan diri peserta didik.

Berdasarkan uraian tersebut, kelebihan model pembelajaran berbasis discovery learning adalah memfasilitasi pembelajaran dalam ranah afektif, kognitif, dan psikomotorik peserta didik, membantu peserta didik memperoleh pengetahuan yang mendalam, serta meningkatkan motivasi belajar peserta didik. Hal ini dikarenakan model pembelajaran discovery learning memfasilitasi siswa untuk menemukan dan membangun sendiri pengetahuannya, sehingga pengetahuan yang diperoleh akan lebih membekas. Namun, Putrayasa et al. (2014, p. 16) berpendapat bahwa pembelajaran berbasis discovery learning akan berhasil apabila diajarkan kepada peserta didik dengan minat belajar tinggi dan kurang efektif apabila diajarkan kepada peserta didik dengan minat belajar rendah. Hal ini dikarenakan peningkatan hasil belajar berbanding lurus dengan minat belajar peserta didik. Peserta didik dengan minat belajar rendah cenderung menyukai keadaan yang stabil, sehingga peserta didik cenderung kurang aktif selama jalannya kegiatan pembelajaran. Kendala tersebut dapat diatasi dengan meyakinkan dan memotivasi peserta didik dengan minat belajar rendah untuk dapat terlibat dalam kegiatan pembelajaran.

Berdasarkan hal tersebut, kendala-kendala yang dihadapi dalam pelaksanaan pembelajaran berbasis discovery learning berkaitan dengan efektifitas waktu pembelajaran, pembagian kelompok diskusi, dan motivasi belajar peserta didik. Kendala tersebut dapat diatasi dengan menciptakan kondisi belajar mengajar yang menyenangkan sehingga peserta didik akan termotivasi, melaksanakan diskusi dalam pemecahan masalah dengan sungguh-sungguh, dan tidak membuang banyak waktu. 


\section{SIMPULAN}

Berdasarkan hasil penelitian, diketahui bahwa implementasi model pembelajaran IPA berbasis discovery learning terintegrasi jajanan lokal daerah efektif meningkatkan lima aspek keterampilan proses sains dasar, yaitu keterampilan mengobservasi dari nilai 3,00 dengan kategori baik menjadi nilai 4,00 dengan kategori sangat baik, mengklasifikasi dari nilai 2,5625 dengan kategori baik menjadi 3,8125 dengan kategori sangat baik, memprediksi dari nilai 1,75 dengan kategori sangat kurang menjadi 3,75 dengan kategori sangat baik, menarik kesimpulan dari nilai 2,3125 dengan kategori kurang menjadi 3,5625 dengan kategori sangat baik, dan mengkomunikasikan dari nilai 2,8125 dengan kategori baik menjadi 3,5 dengan kategori sangat baik. Selain itu, lima aspek keterampilan proses sains terintegrasi juga mengalami peningkatan, yaitu menginterpretasi data dari nilai 2,75 dengan kategori baik menjadi 3,375 dengan kategori sangat baik, mengontrol variabel dari nilai 3,3125 menjadi 3,4375 dengan kategori sangat baik, membuat hipotesis dari nilai 1,8125 dengan kategori kurang menjadi 3,75 dengan kategori sangat baik, mendefinisikan secara operasional dari nilai 3,1875 menjadi 3,25 dengan kategori baik, serta melakukan eksperimen dengan nilai 4,00 dengan kategori sangat baik.

\section{DAFTAR PUSTAKA}

Arends, R. I. (2012). Learning to teach (9th Editio). The McGraw-Hill Companies, Inc.

Ayadiya, N., \& Sumarni, W. (2015). The application of discovery learning with scientific approach to improve the students 'science process skill. Proceedings of The 9 Th Joint Conference on Chemistry, 466-469.

Djamarah, S. B., \& Zain, A. (2010). Strategi belajar mengajar. Rineka Cipta.

Elvanisi, A., Hidayat, S., \& Fadillah, E. N. (2018). Analisis keterampilan proses sains siswa sekolah menengah atas. Jurnal Inovasi Pendidikan IPA, 4(20), 245-252. https://doi.org/10.21831/jipi.v4i2.21426

Faqih, M. I., \& Wilujeng, I. (2018). Memetakan keterampilan proses sains siswa SMP kelas VII di Kabupaten Gunungkidul Yogyakarta. Phenomenon: Jurnal Pendidikan MIPA, 7(2), 187. https://doi.org/10.21580/phen.2017.7.2.1933

Fitri, M., \& Derlina, D. (2015). Pengaruh model pembelajaran discovery learning terhadap hasil belajar siswa pada materi pokok suhu dan kalor. INPAFI (Inovasi Pembelajaran Fisika), 3(2), 89-96. https://doi.org/10.24114/inpafi.v3i2.5130

Hanafi, H. (2016). The effect of discovery learning method application on increasing students' listening outcome and social attitude. DINAMIKA ILMU, 16(2), 291. https://doi.org/10.21093/di.v16i2.552

Hartini, R. I. P. (2017). Penggunaan levels of inquiry dalam meningkatkan keterampilan proses sains siswa. JIPF (Jurnal Ilmu Pendidikan Fisika), 2(1), 19. https://doi.org/10.26737/jipf.v2i1.200

Hayati, I. A., Rosana, D., \& Sukardiyono, S. (2019). Pengembangan modul potensi lokal berbasis SETS. Jurnal Inovasi Pendidikan IPA, 5(2), 248-257. https://doi.org/10.21831/jipi.v5i2.27519

Irianti, R., \& Nurcahyo, H. (2016). Pengembangan SSP model SLH untuk penumbuhkembangan keterampilan proses sains dan karakter peduli lingkungan siswa. Jurnal Inovasi Pendidikan IPA, 2(1), 122. https://doi.org/10.21831/jipi.v2i1.11989

Kartimi, K., Gloria, R. Y., \& Aryani, A. (2013). Penerapan pendekatan keterampilan proses dalam pengajaran biologi untuk mengetahui hasil belajar siswa pada pokok bahasan ekosistem kelas VII di SMPN 1 Talun. Scientiae Educatia: Jurnal Pendidikan Sains, 2(1), 65-76. https://doi.org/10.24235/sc.educatia.v2i1.524

Listyawati, M. (2012). Pengembangan perangkat pembelajaran IPA terpadu di SMP. Journal of Innovative Science Education, 1(1), 61-69. https://journal.unnes.ac.id/sju/index.php/jise/article/view/46

Mundilarto, M. (2015). The effectiveness of thematic learning to improve science process skills of JHS students. Proceeding of International Conference On Research, Implementation And Education Of Mathematics And Sciences, 5, 17-19.

Padilla, M. J. (1990). The science process skills. Research matters-To the science teacher, No. 9004. National Association for Research in Science Teaching (NARST). 


\section{Jurnal Inovasi Pendidikan IPA, 6 (1), 2020 - 124}

Rizki Arumning Tyas, Insih Wilujeng, Suyanta Suyanta

http://www.narst.org/publications/research/skill.cfm

Puspita, L. (2019). Pengembangan modul berbasis keterampilan proses sains sebagai bahan ajar dalam pembelajaran biologi. Jurnal Inovasi Pendidikan IPA, 5(1), 79-88. https://doi.org/10.21831/jipi.v5i1.22530

Putrayasa, I. M., Syahruddin, H., \& Margunayasa, I. G. (2014). Pengaruh model pembelajaran discovery learning dan minat belajar terhadap hasil belajar IPA siswa. Jurnal Mimbar PGSD Universitas Pendidikan Ganesha, 2(1), 14-22. https://doi.org/10.23887/jjpgsd.v2i1.3087

Rahardini, R. R. B., Suryadarma, I. G. P., \& Wilujeng, I. (2017). The effect of science learning integrated with local potential to improve science process skills. AIP Conference Proceedings 1868, 080008. https://doi.org/10.1063/1.4995192

Ratnasari, D., Sukarmin, S., \& Suparmi, S. (2017). Analisis implementasi instrumen two-tier multiple choice untuk mengukur keterampilan proses sains. Jurnal Pendidikan Dan Kebudayaan, 2(2), 166. https://doi.org/10.24832/jpnk.v2i2.627

Roestiyah, N. K. (2012). Strategi belajar mengajar: Salah satu unsur pelaksanaan strategi belajar mengajar (teknik penyajian). Rineka Cipta.

Rosnaeni, R., Muslimin, M., \& Saehana, S. (2018). Perbandingan keterampilan proses sains antara kelompok siswa yang diajar dengan model POE dan model discovery. Jurnal Pendidikan Fisika, 6(1), 43-53. https://doi.org/10.24127/jpf.v6i1.1260

Rostikawati, D. A., \& Permanasari, A. (2016). Rekonstruksi bahan ajar dengan konteks socio-scientific issues pada materi zat aditif makanan untuk meningkatkan literasi sains siswa. Jurnal Inovasi Pendidikan IPA, 2(2), 156. https://doi.org/10.21831/jipi.v2i2.8814

Rusman, R. (2016). Model-model pembelajaran: Mengembangan profesionalisme guru. PT Raja Grafindo Persada.

Siska, B. M., Kurnia, K., \& Sunarya, Y. (2013). Peningkatan keterampilan proses sains siswa sma melalui pembelajaran praktikum berbasis inkuiri pada materi laju reaksi. Jurnal Riset Dan Praktik Pendidikan Kimia, 1(1). http://journal.fpmipa.upi.edu/index.php/jrppk/article/view/216

Subekti, Y., \& Ariswan, A. (2016). Pembelajaran fisika dengan metode eksperimen untuk meningkatkan hasil belajar kognitif dan keterampilan proses sains. Jurnal Inovasi Pendidikan IPA, 2(2), 252261. https://doi.org/10.21831/jipi.v2i2.6278

Sugiyono, S. (2015a). Metode penelitian dan pengembangan. Alfabeta.

Sugiyono, S. (2015b). Metode penelitian pendidikan: Pendekatan kuantitatif, kualitatif, dan $R \& D$. Alfabeta.

Sulistyowati, N., Widodo, A. T., \& Sumarni, W. (2012). Efektivitas model pembelajaran guided discovery learning terhadap kemampuan pemecahan masalah kimia. Chemistry in Education, $1(2)$.

Sya`ban, M. F., \& Wilujeng, I. (2016). Pengembangan SSP zat dan energi berbasis keunggulan lokal untuk meningkatkan literasi sains dan kepedulian lingkungan. Jurnal Inovasi Pendidikan IPA, 2(1), 66-75. https://doi.org/10.21831/jipi.v2i1.8369

Syah, M. (2013). Psikologi pendidikan dengan pendekatan baru. PT Remaja Rosdakarya.

Taqiyyah, S. A., Subali, B., \& Handayani, L. (2017). Implementasi bahan ajar sains berbahasa Inggris berbasis metakognitif untuk meningkatkan kemampuan pemecahan masalah siswa SMP. Jurnal Inovasi Pendidikan IPA, 3(2), 224. https://doi.org/10.21831/jipi.v3i2.14859

Trianto, T. (2014). Model pembelajaran terpadu. Bumi Aksara.

Wenning, C. J. (2011). The levels of inquiry model of science teaching. Journal of Physics Teacher Education Online, 6(2), 9-16. https://www.phy.ilstu.edu/pte/publications/LOI-model-of-scienceteaching.pdf

Widiadnyana, I. W., Sadia, I. W., \& Suastra, I. W. (2014). Pengaruh model discovery learning terhadap pemahaman konsep IPA dan sikap ilmiah siswa SMP. Jurnal Pendidikan Dan Pembelajaran IPA Indonesia, 4(2). https://oldpasca.undiksha.ac.id/e-journal/index.php/jurnal_ipa/article/view/1344

Widoyoko, E. P. (2012). Teknik penyusunan instrumen penelitian. Pustaka Pelajar. 
Jurnal Inovasi Pendidikan IPA, 6 (1), 2020 - 125

Rizki Arumning Tyas, Insih Wilujeng, Suyanta Suyanta

Wilujeng, I., Prasetyo, Z. K., \& Suryadarma, I. G. P. (2017). Science learning based on local potential: Overview of the nature of science (NoS) achieved. AIP Conference Proceedings, 1868(1), 080005. https://doi.org/10.1063/1.4995189 